\title{
The role of reference grammars in school: An interview with Anna Camps, researcher on the teaching of grammar and writing, and Maria Josep Cuenca, linguist
}

\author{
El papel de las gramáticas de referencia en la escuela: Entrevista con \\ Anna Camps, investigadora en didáctica de la gramática y la \\ escritura, y Maria Josep Cuenca, lingüista
}

Marcos Antonio Troncoso

Universitat Autònoma de Barcelona

\begin{abstract}
Anna Camps is a retired Professor from the Universitat Autònoma de Barcelona. She has been the founder and coordinator of the GREAL research group (Grup de Recerca sobre Ensenyament i Aprenentatge de Llengües, the Research Group on Language Teaching and Learning). She has led innovative research projects in Spain on the teaching of written composition, the metalinguistic activity of students and the teaching of grammar.

Maria Josep Cuenca holds a PhD in Catalan Philology and is a Professor at the University of Valencia. Her field of study is syntax, discourse analysis, and linguistics applied to language teaching and translation. She has published works on connectors, interjections, discourse markers, and demonstratives, as well as more general topics on Catalan syntax, text grammar or grammaticalization.
\end{abstract}

Keywords: Congram19; Grammar; Grammar teaching and learning; L1 teaching and learning; Linguistics

\section{Resumen}

Anna Camps es catedrática jubilada de la Universitat Autònoma de Barcelona. Ha sido fundadora y coordinadora del grupo de investigación GREAL (Grup de Recerca sobre Ensenyament i Aprenentatge de Llengües, el Grupo de Investigación en Enseñanza y Aprendizaje de Lenguas). Ha liderado proyectos de investigación innovadores en España sobre la enseñanza de la composición escrita, la actividad metalingüística de los alumnos y la enseñanza de la gramática.

Maria Josep Cuenca es doctora en filología catalana y catedrática en la Universitat de València. Su campo de estudio es la sintaxis, el análisis del discurso y la lingüística aplicada a la enseñanza de lenguas y la traducción. Ha publicado trabajos sobre conectores, interjecciones, marcadores del discurso y demostrativos, además de temas más generales como la sintaxis catalana, la gramática del texto o la gramaticalización.

Palabras clave: Congram19; Enseñanza y aprendizaje de la gramática; Enseñanza y aprendizaje de la L1; Gramática; Lingüística 


\section{THE ROLE OF REFERENCE GRAMMARS IN SCHOOL: AN INTERVIEW WITH ANNA CAMPS, RESEARCHER ON THE TEACHING OF GRAMMAR AND WRIT- ING, AND MARIA JOSEP CUENCA, LINGUIST}

Interviewer: What role should grammar play in L1 learning and teaching?

Camps: The discussion about the need or not to teach grammar at the compulsory educational levels (primary and secondary) has been the subject of wide debates and also of studies that have reached contradictory conclusions, which has led on many occasions to relegate it to a secondary role in Language Arts. The communicative approaches that took over back in the 1970s and 1980s are exponents of this. However, I think that the role that grammatical knowledge should play in compulsory education should be reconsidered based on new approaches. Two reflections as a starting point:

a) The first one is the consideration of the humans' capacity to reflect on one's own language, an ability that develops at the same time as the ability to speak and understand a language. Verbal activity is accompanied by metalinguistic activity. This activity (namely, the one that consists of being able to use the language to reflect on the language that is being used) is developed throughout schooling and is favored by learning the written language. Furthermore, it manifests itself at different levels, from procedural to being verbally expressed in common language or in specialized language.

b) And a second reflection: Literate societies have developed explanatory models about the functioning of languages. These models, like any scientific model, propose categories and concepts as well as a set of terms useful to refer to them; such concepts are articulated in systems that help to understand many aspects of the object of study, namely languages. Scientific models are always open to reformulation in contrast to reality. This also applies to the grammatical models: the diversity of orientations within linguistics simply corroborates it. From the point of view of teaching, it should be considered that the grammar that has been called explicit is not a copy of the linguistic knowledge of the speakers, but rather consists of a socially elaborated model to explain it and that it must be taught.

The grammar teaching model that has supported the GREAL group's research (see Anabella Poggio's review in this Special Issue, Part 2, Bellaterra Journal of Teaching \& Learning Language \& Literature, 13.3) starts from the idea that metalinguistic activity is inherent to the use of language and that it is necessary to 
develop it if we want to improve our elaborate oral and written uses. Based on the children's ability to reflect on the language in use, it will be necessary to introduce the basic concepts that grammatical models have developed to systematically explain how the language works. This will allow students to use these concepts to systematize their observations and to make them more adjusted and effective. Apart from this aspect, which we could call functional, all citizens should have sufficient knowledge to value languages, understand their operation and structure, to compare the languages we know to a greater or lesser degree, etc. We share the idea of the need for language to be an object of knowledge, such as the physical and mathematical world.

Cuenca: Grammar must occupy an important place in the learning and teaching of L1 as a metalanguage that allows us to reflect on both our mother tongue and on other languages. The history of applied linguistics in the field of language teaching in the Spanish/Catalan context shows a pendulum movement in this regard. Traditional approaches (including structuralist proposals, cf. Cuenca 1992, Teories gramaticals $i$ ensenyament de llengües, Valencia, Tàndem), which equated linguistic and grammatical knowledge, have offered uneven results. Communicative approaches have often ended up taking the other extreme, that is, an oversight of grammatical reflection or a superficial approach to grammar contents in language teaching. Or, even worse, they have promoted a mixture of the defects of both perspectives, traditional and communicative. This can lead to the juxtaposition of the communicative and the grammatical aspects, while neglecting that grammatical competence is one component of communicative competence. It has also contributed the endurance of mechanistic practices, where grammatical concepts (like rote learning of definitions of parts of speech or the list of prepositions, to give well-known examples in our context) are replaced by textual concepts, such as the types of text. This 'new' communicative concepts ended up being studied in an equally decontextualized and memory-based way. This implies that grammatical contents (either sentential or textual) are often understood as separate blocks in learning and are subject to rote-learning, which does not lead to a real improvement in communicative skills. The teaching of grammar must therefore aim at improving linguistic and communicative skills in general. Grammar must neither displace other contents nor be displaced by them. It is necessary to adapt the concepts to the level of teaching, reflect on how and when they are introduced and how (in relation, among other factors, to the distinction between explicit and implicit grammar). 
Interviewer: What kinds of proposals should characterize the teaching of grammar in Language Arts?

Camps: I will point out some of the conditions that, in my opinion, should preside over the teaching of grammar at school: 1 . The teaching of grammar should be a reflection on language, the metalinguistic activity, which implies speaking to learn grammar and, therefore, requires verbal interaction that takes language as its object. 2. A grammar model for schooling must consider the formal, semantic, and pragmatic aspects that drive the linguistic forms. 3. It is necessary to establish a relationship between the grammatical content that is learned and the reading and writing activities. 4 . It is also necessary to offer a simple but systematized conceptual framework, away from the atomized exposition of concepts and to offer the students tools to progressively approach the knowledge of grammatical notions. Each one of these four points deserve to be developed in greater depth and to see what implications they have for school practice. I will take up some of these ideas in my answers to the following questions.

Apart from these basic conditions, it is worth considering some characteristics of grammar teaching that allow and encourage reflection on the language as a basis for learning grammar. First, I would highlight the need for students to know and share the objectives of grammar instructional sequences. It is not enough to "do exercises" or "learn definitions" for students to awaken interest in grammar. This reflection led the GREAL group to design what we call Grammar Instructional Sequences (GIS, Seqüències Didàctiques de Gramàtica, SDG, cf. Camps \& Fontich, 2020). These sequences clearly explain the tasks that must be carried out to achieve the proposed objectives, many of which require collaborative work. Verbal interaction in this mode of work triggers abundant verbalized metalinguistic activity: speaking to learn grammar. Such an organization requires students to have reference materials at their fingertips. On the other hand, if we consider the difficulty students at compulsory education face when learning abstract concepts such as the grammatical ones, promoting peer, small group, and class interaction throughout the GIS allows the teacher to intervene in the process so that the learners can overcome the obstacles that grammatical learning represents for them.

Cuenca: In my opinion, teaching grammar must depart from communicative oriented proposals that are usage based, such as those derived from cognitive linguistics in general, and especially from cognitive grammar, which has already been successfully applied in some cases. Structural proposals based on a theoretical approach to language are not ruled out, but they should not be the center of 
pedagogical action since, frequently, they do not have a real impact in improving communicative skills. Teaching must be based on an eclectic but coherent model and this requires a very solid linguistic training and a capacity for a didactic transposition adapted to each level of teaching and to the objective that one wants to achieve at every moment. The grammatical, metalinguistic reflection must take different forms. In this area, in addition to the proposals more based on explicit grammar, the reflections derived from textual transformation activities are interesting. For example, it is easier to understand what a passive construction is and its syntactic and textual restrictions of use if students are asked to transform a text including many active constructions into a version including passive sentences whenever possible, without losing text fluidity and discursive adequacy. Once the transformation task has been carried out, one can reflect on the concept of passive and its types, its relationship with impersonalization, the conditions of passivization and its effects. For instance, an interesting discourse effect of passives and depersonalization in general, as some authors have pointed out, is that these mechanisms can allow justifying morally questionable actions once the agent of the action has disappeared; using impersonal structures makes everything seem the result of "natural" processes, without human intervention and thus it can help manipulate and avoid responsibility.

Interviewer: In your opinion, can these proposals about grammar instruction improve language uses?

Camps: The proposals made in the previous answers aim to relate the knowledge of the language system with the language in context and in use. This does not mean that grammatical knowledge follows directly from verbal uses. The school must teach students to observe the language, to analyze it, to elaborate the concepts, which are abstract, in an orderly manner and must also teach how to use grammatical knowledge to advance in this ability to use language reflexively. In various works I have proposed a double programming path: that of learning verbal, oral and written uses, and that of orderly learning the grammatical system. But these two ways have a wide scope of contact: on the one hand, the problems that arise in comprehension and production activities, especially written ones, give rise to posing problems that require grammatical knowledge, offer examples of diverse solutions to express ideas, etc.; on the other hand, the orderly learning of grammar provides instruments to solve the problems posed, allows us to become aware of the expressive and communicative possibilities of the language, to better understand its nuances, etc. We could compare both types of learning with what an apprentice does when learning to play a musical instrument: on the one hand she is 
capable of executing and executes some musical works, but on the other it is necessary for her to exercise herself in the technical handling of the instrument, to know its possibilities, etc. which will lead her to improve the performance.

Cuenca: Indeed, communicative usage-based proposals must improve language use. Otherwise, the learning process becomes mechanical and either makes no sense or is very limited. Continuing with the example about the passive, if we know when a passive can be used (not with any verb, as the idea of passive voice seems to suggest) and its different types, how it interacts with the active agentive construction and what are its effects, then we can reflect during the textual production process and especially in the revision phase. We can also make cross-linguistic contrast that can lead, for example, to observe differences between the Romance languages, which use less passive, especially periphrastic variants, and English, which uses passives much more. Or genres can be compared, observing in which ones passives are more frequent and appropriate and in which ones their use is weird, unnatural.

Interviewer: What grammatical content do you think compulsory schooling should teach?

Camps: Before referring to the specific content, it should be noted that when students learn grammar at school they are learning three types of content: 1) They learn to take the language as an object of reflection, the components of which can be analyzed and which can become elements to play with to produce the intended effects. In other words, they learn to carry out a metalinguistic activity that will have an effect on the way they understand and speak and write a language. 2) They consciously learn how the language(s) they speak is organized, that is, how the particular languages work: Catalan, Spanish, French, Italian, English, etc. 3) Finally, they learn a conceptual linguistic system (a grammatical model) that will be transferred to learning new languages.

The specific contents that should be considered in the teaching of grammar should go beyond the explanations and exemplification of morphological and syntactic concepts and include the following aspects: 1) Description of the language that approaches semantics and pragmatics as the basis that articulate linguistic forms. 2) Comparisons between the languages in contact within the same territory. 3) A common terminology that allows the transfer of knowledge between languages. 4) Proposals and procedures for linguistic reasoning that allow the construction of basic linguistic concepts; this aspect is generally outside the grammars of languages. Basic language concepts are assumed to be familiar to users of 
handbooks. 5) Inquiry procedures on linguistic uses that invite students to act as "researchers" of the languages in their environment, especially in situations of multilingualism, so frequent today.

Cuenca: Grammar is a metalanguage, which, as I have pointed out, is not a substitute for language learning, but which can enrich and accelerate it, if applied correctly. The most general grammatical terminology and the concepts they name must be taught: the part of speech and sentence functions, the most common sentence types and discursive processes, the properties of the text and the phenomena that drive them, basic concepts of phonology and morphology and also of pragmatics. In addition, work should be done on how to apply them in the analysis, production and transformation of sentences or texts according to grammatical parameters, always taking into account the textual effects they create (at the level of coherence and appropriateness). In other words, grammatical work cannot be mechanical or disconnected from linguistic activity, even when it comes to abstractions or terminological questions.

Interviewer: What features are new grammars emanating from the academy and, in this view, how they should relate to the textbooks?

Camps: The recently published grammars by the Real Academia Española (RAE) and by the Institut d'Estudis Catalans (IEC) provide important novelties to previous grammars. It is not possible in such a short space to make an analysis of each of them and their different versions, much less establish a comparison. I will highlight only two aspects that seem relevant to me. In the first place, the new grammars are not only normative, but emphasize the descriptive aspects of Spanish and Catalan, respectively. On the other hand, at different levels in the different versions, they introduce semantic and pragmatic approaches that can be useful for teachers who want to move away from a purely formal teaching of grammar and, some of them also cater to geographic variation or social registration.

Cuenca: The new grammars of both Catalan and Spanish have a more descriptive orientation than the classical ones and are more attentive to linguistic variation, especially geographic variation. In addition, they present, at least in the case of official Catalan grammars (namely, those edited by the Institut d'Estudis Catalans), a more nuanced approach to the norm, not based on the principle of correction and incorrectness, but on that of adequacy to the communicative context (i.e., formal and informal registers). The standard language is primarily based on description, not in prescription, and has a broader view where there is less 'purism' and each construction are valued in relation to the different registers. This new 
perspective should inspire textbooks, making compatible the wealth of nuances with the simplicity/simplification required according to the educational level. In this sense, the Gramàtica bàsica i d'ús de la llengua catalana (Basic and usage grammar of Catalan language) offers a model for the transposition of the grammatical doctrine that can serve as a starting point for teachers and publishers, although the information must be prepared later for its application in the classroom, adapting, as we said, to the level and the objective pursued. In the case of Catalan, teachers and people who produce textbooks can find both in Gramàtica essencial (Essential grammar, https://geiec.iec.cat, see Presentació) and in Gramàtica bàsica (Basic grammar, https://www.iec.cat/recerca/projecte1.asp?codi=PRS2017-S04-CUENC A) a descriptive and normative starting point, which should be complemented with linguistic aspects of the text and pragmatics, an aspect scarcely considered in academic grammars.

Interviewer: What should be the relationship between the academic study of the language and the didactics / pedagogy applicable to the classroom?

Camps: This is a hotly discussed in the teaching of all the school subjects. What is the relationship between a) the contents that result from academic and scientific research in every field of knowledge and b) the teaching content? It seems clear that the relationship cannot be a simple application from one field to the other. The purposes of research in the field of linguistics does not coincide with those of teaching, and therefore the contents must be adapted to the different contexts and purposes. There has been a debate about the didactic transposition or didactic adaptation.

However, it seems clear that teachers or authors of school material cannot and should not remain unaware of the contributions of science. They must be attentive to what linguistics contributes to critically review what they are teaching. This does not mean that they apply these contributions uncritically, as it often used to happen with the application of structuralist, and later generativist, theories to the teaching of grammar in compulsory education.

On the other hand, I would advocate a greater permeability of linguistic studies to what many teachers involved in language teaching and many researchers in didactics can contribute in terms of linguistic knowledge. For example, knowing the learning processes of language and grammar would perhaps help to rethink the relationships between use, meaning and form in the study of languages and in the organization of reference grammars. 
Cuenca: The academic study of the language is a sine qua non condition of teacher training. If you do not have a deep and extensive knowledge of grammar, you cannot teach a language well. But grammar and language knowledge should not be equated. Knowledge is the theoretical basis for didactic application that teachers and specialists in teaching materials will have to depart from. On the other hand, the work of grammar does not always have to be explicit. The implicit work that can be done through tasks of text production and transformation is very important.

As for linguistic research, there must be a two-way relationship. On the one hand, there must be researchers who build the bridge between research and teaching application. On the other hand, there must be people who apply contents that they must know well and be able to relate to appropriate pedagogical methodologies for their application in the classroom. While the former does not apply to all researchers (not all researchers have to work on applications), the latter is more generalizable (all language teachers should have a sound grammar knowledge). The existence of people who build bridges, especially through work on textbooks and reference material, is key to facilitate the relationship and help to lighten the burden on teachers, who can hardly keep up to date with everything that is done in the academic field.

\section{Marcos ANTONIO TronCOSO}

He is Inspector General and Classroom Professor at the Movilizadores Portuarios public school and at Los Lagos Institute of Higher Education in San Antonio (Chile). He studied at Playa Ancha University (Valparaíso) and is currently studying a master's degree at the UAB, awarded with a scholarship by the Government of Chile. His research focuses on the relationship between teaching grammar and writing.

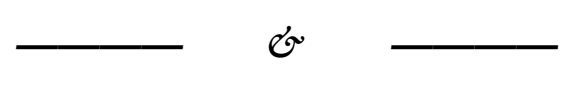




\section{EL PAPEL DE LAS GRAMÁTICAS DE REFERENCIA EN LA ESCUELA: ENTRE- VISTA CON ANNA CAMPS, INVESTIGADORA EN DIDÁCTICA DE LA GRAMÁ- TICA Y LA ESCRITURA, Y MARIA JOSEP CUENCA, LINGÜISTA}

Entrevistador: ¿Qué lugar debe ocupar la gramática en el aprendizaje y la enseñanza de la L1?

Camps: La discusión sobre la necesidad o no de enseñar gramática en los niveles educativos obligatorios (primaria y secundaria) ha sido motivo de amplios debates y también de investigaciones que han llegado a conclusiones contradictorias, lo cual ha llevado en muchas ocasiones a relegar la enseñanza gramatical de la enseñanza de la lengua. Las aproximaciones comunicativas que dominaron a partir de los años 70 son exponentes de ello. Sin embargo, creo que habría que reconsiderar el lugar que debe ocupar el conocimiento gramatical en la enseñanza obligatoria a partir de nuevos planteamientos. Dos reflexiones como punto de partida:

a) La primera es la consideración de la capacidad humana de reflexionar sobre la propia lengua. Capacidad que se desarrolla al mismo tiempo que lo hace la capacidad de hablar y comprender una lengua. La actividad verbal va acompañada de la actividad metalingüística. Dicha actividad, es decir la que consiste en poder reflexionar sobre la lengua que se usa, se desarrolla a lo largo de la escolaridad y se ve favorecida por el aprendizaje de la lengua escrita. Además, se manifiesta a diferentes niveles, desde los procedimentales a los expresados verbalmente en lenguaje común o en lenguaje especializado.

b) La segunda reflexión: Las sociedades alfabetizadas han elaborado modelos explicativos, sobre el funcionamiento de las lenguas. Estos modelos, como cualquier modelo científico han propuesto categorías y conceptos y les han atribuido términos que son útiles para referirse a ellos; conceptos que se articulan en sistemas que ayudan a comprender muchos aspectos del objeto de estudio, las lenguas. Los modelos científicos están siempre abiertos a su reformulación en contraste con la realidad. También los modelos gramaticales lo están, y, además, la diversidad de orientaciones de los estudios lingüísticos no hace más que corroborar esta afirmación. Desde el punto de vista de la enseñanza se debe considerar que la gramática que se ha denominado explícita no es un calco del conocimiento lingüístico de los hablantes, sino que consiste en un modelo elaborado socialmente para explicarlo y que debe ser enseñado. 
El modelo de enseñanza de la gramática que ha sustentado hasta ahora las investigaciones del grupo GREAL (para la trayectoria de este grupo, ver reseña de Anabella Poggio en la segunda parte de este monográfico, Bellaterra Journal of Teaching \& Learning Language \& Literature 13.3) se basa en la idea de que la actividad metalingüística es inherente al uso de la lengua y es necesario desarrollarla para avanzar en los usos elaborados orales y escritos. A partir de la capacidad de los niños y niñas de reflexionar sobre la lengua en uso será necesario introducir los conceptos básicos que los modelos gramaticales han elaborado para explicar de forma sistemática el funcionamiento de la lengua. Ello hará posible que los escolares puedan usar estos conceptos para sistematizar sus observaciones y para hacerlas más ajustadas y eficaces.

A parte de este aspecto, que podríamos denominar funcional, todos los ciudadanos deberíamos tener los conocimientos suficientes para valorar las lenguas, comprender su funcionamiento y su estructura, para comparar las lenguas que conocemos en mayor o menor grado, etc. Compartimos la idea de la necesidad de que la lengua sea objeto de conocimiento en sí misma, como lo son el mundo físico, el matemático, etc.

Cuenca: La gramática debe ocupar un lugar importante en el aprendizaje y la enseñanza de la L1 como metalenguaje que permite reflexionar sobre el lenguaje, sobre la propia lengua y también sobre las otras lenguas. La historia de la lingüística aplicada a la enseñanza de lenguas muestra un movimiento pendular a este respecto. Si las aproximaciones tradicionales (incluyendo las de corte estructuralista, cf. Cuenca 1992, Teories gramaticals i ensenyament de llengües, Valencia, Tàndem) equiparaban conocimiento lingüístico y gramatical, con resultados desiguales, las comunicativas con frecuencia han acabado llevando al otro extremo (un olvido de la reflexión gramatical o un trabajo superficial de lo gramatical en la enseñanza) o, peor aún, a una mezcla de los defectos de ambas perspectivas. Ello puede llevar a yuxtaponer lo comunicativo y lo gramatical, olvidando que la competencia gramatical es uno de los ejes de la competencia comunicativa. También ha contribuido a mantener prácticas didácticas mecanicistas, donde los conceptos gramaticales (como el aprendizaje mecánico de las definiciones de las partes de la oración o la lista de preposiciones, por poner ejemplos conocidos) se ven sustituidos por conceptos textuales, como los tipos de texto, que acaban estudiándose de manera igualmente descontextualizada y memorística. Ello implica que con frecuencia los contenidos de gramática (oracional o textual) se acaban entendiendo como un bloque separado en el aprendizaje, sujeto a un trabajo memorístico que no conduce a una mejora real en las destrezas. 
La enseñanza de la gramática debe estar, pues, orientada a la mejora en las destrezas lingǘsticas y comunicativas en general. No debe ni desplazar otro tipo de contenidos ni tampoco ser desplazada por ellos. Hay que calibrar en qué nivel se introducen los conceptos y cómo (en relación, entre otros factores, con la distinción entre gramática explícita e implícita).

Entrevistador: ¿Qué tipo de propuestas deberían caracterizar la enseñanza de la gramática?

Camps: Apuntaré algunas de las condiciones que, a mi modo de ver, deberían presidir la enseñanza de la gramática en la escuela: 1 . La enseñanza de la gramática debería basarse en la actividad de reflexión sobre la lengua, la actividad metalingüística, lo cual implica hablar para aprender gramática y, por lo tanto, hace necesaria la interacción verbal que toma como objeto la lengua. 2. La gramática para la enseñanza debe tener en cuenta los aspectos formales, semánticos y pragmáticos que vehiculan las formas lingüísticas. 3. Sería necesario establecer relación entre los contenidos gramaticales que se aprenden y las actividades de lectura y escritura. 4. Es necesario ofrecer un marco conceptual sencillo pero sistematizado, alejado de la exposición atomizada de conceptos y ofrecer a los alumnos instrumentos para abordar el progresivo conocimiento de las nociones gramaticales. Cada una de ellas merecería ser desarrollada con mayor profundidad y ver qué implicaciones tiene para la práctica escolar. Retomaré algunas de estas ideas en las respuestas a las preguntas siguientes.

A parte de estas condiciones básicas cabe tener en cuenta algunas características de la enseñanza gramatical que pueden permitir y fomentar la reflexión sobre la lengua como base para el aprendizaje de la gramática. Destacaría en primer lugar la necesidad de que los alumnos conozcan y compartan los objetivos de cada secuencia de enseñanza de la gramática. No basta con "hacer ejercicios" o "aprender definiciones" para que en los alumnos se despierte el interés por la gramática. Esta reflexión llevó al grupo GREAL al diseño de lo que denominamos Secuencias Didácticas de Gramática (SDG). En dichas secuencias se explicitan claramente las tareas que hay que llevar a cabo para alcanzar los objetivos propuestos, muchas de las cuales requieren trabajo en colaboración. La interacción verbal en esta modalidad de trabajo desencadena abundante actividad metalingüística verbalizada: se habla para aprender gramática. Una organización de este tipo requiere que los alumnos dispongan de materiales de consulta a su alcance. Por otro lado, si consideramos la dificultad que representa para los alumnos de la enseñanza obligatoria el dominio de conceptos abstractos como son los gramaticales, una organización 
del trabajo que permita la interacción verbal entre los alumnos y con el profesor a lo largo de la SDG permite a este intervenir en el proceso para que los aprendices puedan superar los obstáculos que el aprendizaje gramatical representa para ellos.

Cuenca: Las propuestas de orientación comunicativa y las basadas en el uso, como las derivadas de la lingüística cognitiva, en general, y, especialmente, de la gramática cognitiva, que se ha aplicado ya con éxito en algunos casos. Las propuestas más estructurales y basadas en una concepción teórica del lenguaje no son descartables, pero no deben ser el centro de la actuación pedagógica pues, con frecuencia, no inciden en una mejora de destrezas real. La enseñanza debe basarse en un modelo ecléctico al tiempo que coherente y ello requiere una formación lingüística muy sólida y una capacidad de transposición didáctica adaptada a cada nivel y al objetivo que en cada momento se quiere conseguir.

La reflexión gramatical, metalingüística, debe adoptar diferentes formas. En este ámbito, además de las propuestas más basadas en la gramática explícita, son interesantes las reflexiones derivadas de actividades de transformación textual. Por ejemplo, es más fácil entender qué es una pasiva y qué limites sintácticos y textuales presenta si se ofrece un texto con muchas construcciones activas y se pide que se transforme en pasiva, siempre que sea posible, sin perder la naturalidad y adecuación discursivas. Una vez realizada la tarea de transformación, se puede reflexionar sobre el concepto de pasiva y sus tipos, su relación con la impersonalización, las condiciones de la pasivización y sus efectos. Así, la despersonalización, como han estudiado algunos autores, puede permitir justificar actuaciones moralmente cuestionables una vez ha desaparecido el agente de la acción; su uso hace parecer que todo se produce de manera 'natural', sin intervención humana y, con ello, se puede manipular el discurso y eludir responsabilidades.

Entrevistador: Según su opinión, ¿pueden estas propuestas mejorar los usos?

Camps: Las propuestas formuladas en las respuestas anteriores apuntan a relacionar el conocimiento del sistema de la lengua con la lengua en contexto y en uso. Ello no significa que el conocimiento gramatical se desprenda directamente de los usos verbales. La escuela debe enseñar a los alumnos a observar la lengua, a analizarla, a elaborar los conceptos, que son abstractos, de forma ordenada y deberá enseñar también a utilizar los conocimientos gramaticales para avanzar en esta capacidad de usar reflexivamente la lengua.

En diversos trabajos he propuesto una doble vía de programación: la de aprendizaje de los usos verbales, orales y escritos, y la del aprendizaje ordenado del 
sistema gramatical. Pero estas dos vías tienen un amplio ámbito de contacto: por un lado los problemas surgidos en las actividades de comprensión y producción, especialmente escritas, dan lugar a plantear problemas que requieren en concurso del conocimiento gramatical, ofrecen ejemplos de soluciones diversas para expresar la ideas, etc.; por otro lado el aprendizaje ordenado de la gramática va proporcionando instrumentos para resolver problemas planteados, permite tomar conciencia de las posibilidades expresivas y comunicativas de la lengua, de comprender mejor sus matices, etc. Podríamos comparar ambos tipos de aprendizaje con lo que hace un aprendiz de un instrumento musical: por un lado es capaz de ejecutar y ejecuta algunas obras, pero por otro le es necesario ejercitarse en el manejo técnico del instrumento, conocer sus posibilidades, etc., lo cual le llevará a mejorar su interpretación.

Cuenca: Deben mejorarlos. Si no lo hacen, el aprendizaje resulta mecánico y deja de tener sentido o lo tiene de manera muy limitada. Siguiendo con el ejemplo de la pasiva, si sabemos cuándo se puede utilizar la pasiva (no con cualquier verbo, como parece sugerir la idea de voz pasiva) y sus diferentes tipos, cómo interactúa con la construcción activa agentiva y cuáles son sus efectos, podemos reflexionar durante el proceso de producción textual y sobre todo en la fase de revisión. También podemos realizar contrastes interlingüísticos que pueden conducir, por ejemplo, a observar diferencias entre las lenguas románicas, que la utilizan menos, sobre todo en la variante perifrástica, y el inglés, que la utiliza mucho más. $O$ entre géneros, observando en cuáles son más frecuentes y adecuadas y en cuáles resulta extraño su uso, poco natural.

Entrevistador: ¿Qué contenidos gramaticales cree que debería impartir la escuela?

Camps: Previamente a referirnos a contenidos concretos convendría destacar que cuando los alumnos aprenden gramática en la escuela están aprendiendo tres tipos de contenidos: 1) Aprenden a tomar la lengua como objeto de reflexión, cuyos componentes pueden ser analizados y con los cuales se puede jugar para producir los efectos que se pretenden. Es decir, aprenden a llevar a cabo una actividad metalingüística que tendrá efectos en su forma de comprender y hablar y escribir una lengua. 2) Aprenden de manera consciente cómo está organizada la lengua (las lenguas) que hablan, es decir cómo funcionan las lenguas particulares: catalán, castellano, francés, italiano, inglés, etc. 3) Por último aprenden un sistema conceptual lingüístico (un modelo gramatical) que se transferirá al aprendizaje de nuevas lenguas. 
Los contenidos específicos que deberían tomarse en consideración en la enseñanza de la gramática deberían ir más allá de las explicaciones y ejemplificación de conceptos morfológicos y sintácticos y tener en cuenta los aspectos siguientes: 1) Descripción de la lengua que tenga en cuenta los aspectos formales, los semánticos y pragmáticos que vehiculan las formas lingüísticas. 2) En situaciones de lenguas en contacto, comparaciones entre las lenguas que concurren en un mismo territorio. 3) Una terminología común que permita la transferencia de conocimientos entre una y otras lenguas. 4) Propuestas de procedimientos de razonamiento lingǘstico que permitan la construcción de los conceptos lingüísticos básicos. Este aspecto queda en general al margen de las gramáticas de las lenguas. Se presupone que los conceptos lingüísticos básicos son conocidos por los usuarios de los manuales. 5) Procedimientos de indagación sobre los usos lingüísticos que promuevan que los alumnos actúen como "investigadores" de las lenguas de su entorno, especialmente en las situaciones de plurilingüismo, tan frecuentes en nuestros días.

Cuenca: La gramática es un metalenguaje, que, como he indicado, no sustituye el aprendizaje lingüístico, pero que lo puede enriquecer y acelerar, si se aplica bien. Se debe enseñar la terminología gramatical más general y los conceptos que denominan: las categorías gramaticales y las funciones oracionales, los procesos oracionales y discursivos más habituales, las propiedades del texto y los fenómenos que las vehiculan, conceptos básicos de fonología y morfología y también de pragmática. Además, se debe trabajar cómo aplicarlos en el análisis y en la producción y transformación de enunciados o textos a partir de parámetros gramaticales, teniendo siempre en cuenta los efectos textuales que crean (en el nivel de coherencia y adecuación). Es decir, el trabajo gramatical no puede ser mecánico o estar desvinculado de la actividad lingüística, incluso cuando se trata de abstracciones o de cuestiones terminológicas.

Entrevistador: ¿Qué características tienen las nuevas gramáticas emanadas de las academias y, a su juicio, cómo se deberían relacionar con los libros de texto?

Camps: Las gramáticas recientemente publicadas por la RAE y por el IEC aportan novedades importantes a gramáticas anteriores. No es posible en tan poco espacio hacer un análisis de cada una de ellas y de sus distintas versiones y mucho menos establecer una comparación. Destacaré únicamente dos aspectos que me parecen relevantes. En primer lugar, las nuevas gramáticas no son únicamente normativas, sino que acentúan los aspectos descriptivos de la lengua castellana y catalana respectivamente. Por otro lado, a niveles diversos en las distintas versiones, introducen enfoques semánticos y pragmáticos que pueden ser útiles para el 
profesorado que quiera alejarse de una enseñanza puramente formal de la gramática y, algunas de ellas también atienden a la variación geográfica o de registro social.

Cuenca: Las nuevas gramáticas tienen una orientación más descriptiva que las clásicas y están más atentas a la variación lingüística, sobre todo la geográfica. Además, presentan, al menos en el caso de las gramáticas del IEC, una aproximación más matizada de la norma, no basada en el principio de corrección e incorrección, sino en el de adecuación al contexto comunicativo. La norma se basa en la descripción y tiene una visión más amplia en la que hay menos 'purismo' y se valora cada construcción en relación con los registros. Esta nueva perspectiva tiene que pasar a los libros de texto, haciendo compatible la riqueza de matices con la simplicidad/simplificación necesaria según el nivel educativo. En este sentido, la Gramàtica bàsica $i$ d'ús de la llengua catalana ofrece un modelo de transposición de la doctrina gramatical que puede servir de punto de partida para docentes y editoriales, si bien la información debe elaborarse ulteriormente para su aplicación en el aula, adaptándose, como decíamos, al nivel y al objetivo que se persigue. En el caso del catalán, los docentes y las personas que elaboran libros de texto pueden encontrar en la Gramàtica essencial (https://geiec.iec.cat, cf. Presentació) i en la Gramàtica bàsica (https://www.iec.cat/recerca/projecte1.asp?codi=PRS2017-S04-CUENC A) un punto de partida descriptivo y normativo, que deberá complementarse con aspectos de lingüística del texto y pragmática, aspecto poco tenido en cuenta en las gramáticas académicas.

Entrevistador: A su juicio, ¿qué relación debería existir entre el estudio académico de la lengua y la didáctica aplicable al aula?

Camps: Este es un tema muy tratado en las didácticas de todas las materias escolares ¿Cuál es la relación entre los contenidos resultado de las investigaciones académicas y científicas en cada campo del saber y los contenidos de enseñanza? Parece claro que la relación no puede ser de simple aplicación de un campo al otro. Las finalidades de la investigación en el campo de la lingüística no son coincidentes con las de la enseñanza y por lo tanto los contenidos deberán adecuarse a los contextos y a las finalidades distintas en uno y otro. Se ha hablado de transposición didáctica o de adecuación didáctica.

Ahora bien, parece claro que los docentes o los autores de manuales escolares no pueden ni deben permanecer ajenos a las aportaciones de la ciencia. Deben estar atentos a lo que la lingüística aporta para poder revisar críticamente lo que están enseñando. Esto no quiere decir que apliquen acríticamente dichas 
aportaciones como ocurrió muy a menudo con la aplicación de las teorías estructuralistas, y después las generativistas, a la enseñanza de la gramática en la enseñanza obligatoria.

Por otro lado, yo abogaría por una mayor permeabilidad de los estudios lingüísticos a lo que muchos profesores implicados en la enseñanza de la lengua y muchos investigadores en didáctica pueden aportar al conocimiento lingüístico. Por ejemplo, conocer los procesos de aprendizaje de la lengua y de la gramática ayudaría quizás a repensar las relaciones entre uso, significado y forma en el estudio de las lenguas y en la organización de las gramáticas de referencia.

Cuenca: El estudio académico de la lengua es condición sine qua non de la formación del docente. Si no se tiene un conocimiento profundo y extenso de la gramática, no se puede enseñar bien una lengua. Pero no hay que equipararlos. El conocimiento es la base teórica de la aplicación didáctica que docentes y especialistas en materiales docentes tendrán que realizar. Por otro lado, el trabajo de la gramática no tiene que ser siempre explícito. El trabajo implícito, que se puede realizar a través de tareas de producción y transformación de textos, es muy importante.

En cuanto a la investigación lingüística, debe haber una relación bidireccional: por un lado, tiene que haber investigadores que faciliten el puente entre la investigación y la aplicación didáctica; por otro lado, las personas que aplican contenidos deben conocerlos bien y ser capaces de relacionarlos con metodologías pedagógicas adecuadas para su aplicación en el aula. Si en el primer caso la condición no se aplica a todas las personas (no todos los investigadores e investigadoras tienen que trabajar en aplicaciones), en el segundo la aplicación es más generalizable. La existencia de personas que hagan de puente, sobre todo a través del trabajo en libros de texto y material de consulta, es esencial para facilitar la relación y contribuir a aligerar el peso sobre los docentes, que difícilmente pueden estar al día de todo lo que se hace en el ámbito académico. 


\section{Marcos ANTONIO TronCOSO}

Es Inspector General y Profesor de Aula en la escuela pública Movilizadores Portuarios y en el Instituto de Educación Superior Los Lagos en San Antonio (Chile). Estudió en la Universidad de Playa Ancha (Valparaíso) y actualmente cursa un máster en la UAB, becado por el Gobierno de Chile. Su investigación se centra en la relación entre la enseñanza de la gramática y la escritura.

$\underline{\text { https://orcid.org/0000-0002-6480-1785 }}$

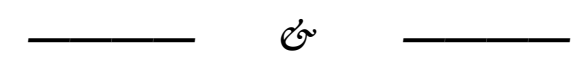

Troncoso, M. A. (2020). The role of reference grammars in school: An interview with Anna Camps, researcher on the teaching of grammar and writing, and Maria Josep Cuenca, linguist. Bellaterra Journal of Teaching \& Learning Language \& Literature, 13(2), e906.

https://doi.org/10.5565/rev/jt13.906 